\title{
Effect of maturity and hybrid on ruminal and intestinal digestion of corn silage in dry cows
}

\author{
J. Peyrat, ${ }^{*} \dagger$ R. Baumont, ${ }^{*}$ A. Le Morvan, ${ }^{*}$ and P. Nozière ${ }^{* 1}$ \\ *INRA, UMR1213 Herbivores, F-63122 Saint-Genès-Champanelle and Clermont Université, VetAgro Sup, UMR Herbivores, BP 10448, F-63000, \\ Clermont-Ferrand, France \\ †ARVALIS-Institut du Végétal, Station Expérimentale de la Jaillière, 44370 La Chapelle-Saint-Sauveur, France
}

\begin{abstract}
The aim of this study was to evaluate the effect of stage of maturity at harvest on extent of starch, neutral detergent fiber (NDF), and protein digestion, and rumen fermentation in dry cows fed whole-plant corn silage from different hybrids. Four nonlactating Holstein cows cannulated at the rumen and proximal duodenum were fed 4 corn silages differing in hybrid (flint vs. flintdent) and maturity stage (early vs. late) in a $4 \times 4$ Latin square design. From early to late maturity, starch content increased (from 234.5 to $348.5 \mathrm{~g} / \mathrm{kg}$ ), whereas total-tract (99.7 to $94.5 \%$ ) and ruminal starch digestibility (91.3 to $86.5 \%)$ decreased significantly. The decrease in ruminal starch digestibility with increasing maturity was similar between hybrids. No effects were found of maturity, hybrid, or maturity $\times$ hybrid interaction on total-tract NDF digestibility, ruminal NDF digestibility, true digestibility of $\mathrm{N}$ and organic matter in the rumen, or microbial synthesis. Harvesting at later maturity led to increased ruminal ammonia, total volatile fatty acid concentrations, and acetate/ propionate ratio but not $\mathrm{pH}$. This study concludes that delaying date of harvest modifies the proportions of digestible starch and NDF supplied to cattle. Adjusting date of corn harvest to modulate amount of rumendigested starch could be used as a strategy to control nutrient delivery to ruminants.
\end{abstract}

Key words: corn silage, ruminal digestion, starch, neutral detergent fiber

\section{INTRODUCTION}

The high voluntary intake and energy density of corn silage makes it the main source of energy in the winter diets of high-yielding ruminants such as lactating cows. Whole-plant energy fractions vary with stage of maturity at harvest, hybrid, and climatic conditions (Opsi

Received February 13, 2015.

Accepted September 13, 2015.

${ }^{1}$ Corresponding author: pierre.noziere@clermont.inra.fr et al., 2013), which can change the type of dietary energy provided by corn silage. Ruminal starch digestion plays a big role by providing both energy for microbial growth, and propionate as the main glucose precursor for milk synthesis. However, ruminal NDF digestion contributes to rumen fill and ensures good rumen function. Fast starch fermentation has been shown to reduce ruminal $\mathrm{pH}$, inhibit fiber digestibility, and thereby increase the risk of digestive disorders (Beauchemin and Yang, 2005). Studies exploring the variability of corn digestion in cattle have investigated the effects of genotype (Taylor and Allen, 2005; Verbic et al., 2005) and grain processing (Huntington, 1997; Johnson et al., 2002; Fernandez et al., 2004) on ruminal starch digestion measured in situ (Lopes et al., 2009; Ali et al., 2014) and in vitro (Tang et al., 2011; Opsi et al., 2013). However, most of the in vivo studies (Bal et al., 1997; Fernandez et al., 2004) available have focused on starch from concentrate-supplemented corn silage diets. To our knowledge, the effect of maturity stage has never been tested in diets where corn silage is the sole source of starch. Another issue is the lack of nutritive value references on corn silage with recent hybrids harvested at late maturity, which have become the mainstay of on-farm practices. In addition, further advances in feed unit systems hinge on acquiring more knowledge on the degradation of starch from forage to gain a better grasp of OM truly digested in the rumen (OMtDR) and microbial protein supply (Van Duinkerken et al., 2011; Volden, 2011; Sauvant and Nozière, 2016). We hypothesized that the effect of maturity at harvest on ruminal starch and NDF degradability measured in situ (Peyrat et al., 2014a) also affects ruminal digestion in vivo. The objective of this study was to quantify the effect of maturity stage on amount of starch and fiber digested in the rumen and intestine, and their effects on microbial $\mathrm{N}$ flow and OMtDR.

\section{MATERIALS AND METHODS}

The experiment was led at the National Institute for Agricultural Research (INRA) at Saint-Genès-Cham- 
panelle (France) experimental farm in full compliance with national legislation on animal care (authorization to experiment on living animals was issued by the French Ministry of Agriculture under certificate no. 63-30 and 63-158). The experiment was approved by the Auvergne region institutional review boards for experiments involving animals (number CE 54-12).

\section{Growing and Conditioning of the Corn Hybrids}

Corn hybrids were grown and harvested at the INRA's Crouël experimental farm in France $\left(45^{\circ} 46^{\prime} \mathrm{N}\right.$; $03^{\circ} 09^{\prime} \mathrm{E}$; $350 \mathrm{~m}$ above sea level; clay-limestone soil). Two corn hybrids were selected for their contrasted grain texture (determining rate of starch degradation) and in vitro digestibility of nonstarch and nonsoluble carbohydrate (IVDNSC; Barrière et al., 1997). The hybrids, named hybrid flint grain $(\mathbf{F})$ and hybrid flint-dent grain (FD), differed on earliness index (early, noted as SA for hybrid FD; late, noted as SB for hybrid F). These hybrids were harvested in 2012 at 2 dates of maturity (i.e., early stage at $<300 \mathrm{~g} / \mathrm{kg}$ of $\mathrm{DM}$ to late stage at $>400 \mathrm{~g} / \mathrm{kg}$ of DM; Table 1). The growth cycle of the hybrids was characterized by a rainfall deficit $(2 \mathrm{~mm}$ average rainfall for all cycles in the field and $2.6 \mathrm{~mm}$ of regional average rainfall for the same period) and hot temperature during grain maturation (cumulative temperature from flowering to late harvest was $785^{\circ} \mathrm{C}$ for $\mathrm{F}$ and $813^{\circ} \mathrm{C}$ for $\mathrm{FD}$ ). Yield, percentage of ear in the whole plant, and DM content of ear and stemleaf fractions were recorded the day before harvest to characterize maturity. The corn was harvested using a precision-chop silage harvester [John Deere 7400 with a 6-row corn header and corn cracker $(3-\mathrm{mm}$ roll clearance); John Deere, Moline, IL] at a stubble height of 15 to $20 \mathrm{~cm}$. Harvested corn was then stored in bag silos $(15 \mathrm{~m} \times 1.8 \mathrm{~m})$ under anaerobic conditions. After 12 wk of fermentation, the silages were sampled to assess quality of conservation by analyzing their fermentation products according to Dulphy and Demarquilly (1981).

\section{Animals, Diets, and Experimental Design}

Four nonlactating Holstein cows weighing $676 \pm 26$ $\mathrm{kg}$ (mean $\pm \mathrm{SD}$ ) were used. The cows had been fitted 3 years earlier with ruminal cannulas (outer/inner diameter $=123 / 106 \mathrm{~mm}$ ) made of polyamide-polyvinyl chloride, and T-shaped cannulas (outer/inner diameter $=30 / 19 \mathrm{~mm}$ ) made of plastisol with a gutter-type flange placed at the proximal duodenum, before the bile duct entrance. All the cannulas had been custommanufactured by the INRA. For this study, the cows were penned in individual stalls and given a nonexperimental corn silage ad libitum during a preexperimental period of $3 \mathrm{wk}$. Treatments were applied in a $4 \times 4$ Latin-square design with 4 corn silage-based experimental treatments differing according to hybrid ( $\mathrm{F}$ or FD) and stage of maturity (early or late). Each period lasted $3 \mathrm{wk}$. Cows were fed at an intake level of $2 \%$ of their BW (i.e., $95 \%$ of voluntary intake during the preexperimental period). The animals were fed twice daily in 2 equal meals at 0830 and $1630 \mathrm{~h}$. To ensure rumen nitrogen balance in each dietary treatment, the corn silages were supplemented daily with $15 \mathrm{~g}$ of urea per $\mathrm{kg}$ of DM (sprinkled on the silage). The animals also received $250 \mathrm{~g} / \mathrm{d}$ of a mineral and vitamin mix (Galaphos Midi Duo 4.5\% P, 20\% Ca, Mg 4.5\%, 5\% $\mathrm{Na}$; CCPA, Janzé, France) and had free access to water and mineral salts.

\section{Measurements and Sampling}

Intake and Weight. In each experimental period, the cows were weighed at the start of wk 1 and at the end of the trial. For each period, intake was recorded on 4 consecutive days in wk 1 and daily in wk 2 to wk 3 . The DM content of corn silage offered and refused was calculated daily by drying samples for $24 \mathrm{~h}$ at $103^{\circ} \mathrm{C}$ in a forced-air oven, then correcting for lost volatile fermentation products (ethanol, $\mathrm{NH}_{3}-\mathrm{N}$, and acetic and lactic acids; Dulphy et al., 1975). For chemical composition analysis, $100 \mathrm{~g}$ of each offered silage and $10 \%$ of refusals were sampled daily in wk 3 , pooled per animal $\times$ period, and stored at $-20^{\circ} \mathrm{C}$.

Total-Tract Digestibility and Nitrogen Balance. Total-tract digestibility and nitrogen balance were determined by collecting total feces and urine over $6 \mathrm{~d}$ of wk 3. To collect urine separately from feces, the cows were fitted with a flexible pipe connected to a $30-\mathrm{L}$ vat containing $500 \mathrm{~mL}$ of $30 \%$ sulfuric acid. Total daily fresh fecal output of each cow was weighed daily at $0900 \mathrm{~h}$. A $1 \%$ aliquot was dried at $103^{\circ} \mathrm{C}$ for $24 \mathrm{~h}$ to determine DM content. Another $0.5 \%$ aliquot was pooled per animal and per period and stored at $-20^{\circ} \mathrm{C}$ to determine chemical composition. Likewise, total urine output of each cow was weighed daily at 0900 h. A 1\% aliquot was pooled per animal and per period and stored at $-20^{\circ} \mathrm{C}$ to determine $\mathrm{N}$ content. Another $0.25 \%$ aliquot was diluted in water (urine/ $\mathrm{H}_{2} \mathrm{O}, 1 / 3 \mathrm{vol} / \mathrm{vol}$ ), pooled per animal and per period, and stored at $-20^{\circ} \mathrm{C}$ to determine purine derivatives.

Nutrient Duodenal Flow and Microbial Synthesis. Duodenal nutrient flow was determined using both external and internal indigestible markers, as recommended by Cochran et al. (1986). Ytterbium (III) chloride $\left(\mathrm{YbCl}_{3}\right)$ was used as an external marker (Siddons et al., 1985) and ADL content (expressed minus residual ash) was used as an internal marker (Kozloski 
Table 1. Characteristics at harvest, chemical composition, and nutritive value of the corn silage [mean and (standard deviation) when available]

\begin{tabular}{|c|c|c|c|c|}
\hline Item & \multicolumn{2}{|c|}{ Hybrid flint } & \multicolumn{2}{|c|}{ Hybrid flint-dent } \\
\hline Yield, $\mathrm{t}$ of DM/ha & \multicolumn{4}{|c|}{ Characteristics of the plant at harvest $(\mathrm{n}=4)^{1}$} \\
\hline Dry matter of fresh plant, $\mathrm{g} / \mathrm{kg}$ of fresh matter $(\mathrm{FM})$ & $313(1.2)$ & $465(3.2)$ & $298(1.6)$ & $489(4.0)$ \\
\hline Ear/whole plant, $\mathrm{g} / \mathrm{kg}$ of DM & $484(13.2)$ & $555(4.6)$ & $472(16.2)$ & $566(14.8)$ \\
\hline Dry matter of ear fraction, $\mathrm{g} / \mathrm{kg}$ of $\mathrm{FM}$ & $357(6.6)$ & $540(16.2)$ & $388(16.4)$ & $577(22.0)$ \\
\hline \multicolumn{5}{|l|}{$\mathrm{pH}$ and fermentation products in silage ${ }^{3}$} \\
\hline $\mathrm{pH}$ & 3.62 & 3.79 & 3.69 & 3.77 \\
\hline Alcohol, g/kg of DM & 7.6 & 4.7 & 3.9 & 8.3 \\
\hline VFA, g/kg of DM & 11.9 & 8.6 & 10.6 & 10.0 \\
\hline Acetate & 11.8 & 8.5 & 10.5 & 9.9 \\
\hline Propionate & 0.07 & 0.04 & 0.06 & 0.05 \\
\hline Butyrate & 0.03 & 0.01 & 0.02 & 0.02 \\
\hline $\mathrm{NDF}, \mathrm{g} / \mathrm{kg}$ of $\mathrm{DM}$ & $398(11.8)$ & $386(29.6)$ & $374(14.4)$ & $321(26.8)$ \\
\hline $\mathrm{ADF}, \mathrm{g} / \mathrm{kg}$ of $\mathrm{DM}$ & $208(9.4)$ & $204(14.4)$ & $200(5.4)$ & $164(10.6)$ \\
\hline $\mathrm{ADLo}, \mathrm{g} / \mathrm{kg}$ of $\mathrm{DM}$ & $18.5(0.48)$ & $18.9(1.36)$ & $14.5(0.40)$ & $12.2(0.82)$ \\
\hline Starch, g/kg of DM & $205(11.2)$ & $312(17.4)$ & $264(18.0)$ & $385(27.2)$ \\
\hline & $12.2(0.64)$ & $11.8(0.58)$ & $13.6(0.38)$ & $12.2(0.18)$ \\
\hline \multicolumn{5}{|l|}{ Nutritive value, ${ }^{6} / \mathrm{kg}$ of DM } \\
\hline $\mathrm{NE}_{\mathrm{L}}, \mathrm{MJ}$ & 6.09 & 6.10 & 6.31 & 6.66 \\
\hline Digestible protein, $\mathrm{g}$ of $\mathrm{PDIE}^{7}$ & 65.4 & 62.2 & 66.8 & 63.2 \\
\hline Digestible protein, $\mathrm{g}$ of $\mathrm{PDIN}^{8}$ & 50.2 & 45.3 & 50.6 & 44.9 \\
\hline
\end{tabular}

${ }^{1}$ Means and standard deviation of 4 sub-plots within each plot sampled the day before harvest.

${ }^{2}$ Estimated by NIRS on pooled samples.

${ }^{3}$ Estimated on pooled samples.

${ }^{4}$ Means and standard deviation of the 4 periods.

${ }^{5}$ The ADLo content was determined after cellulose solubilization with sulfuric acid and expressed minus residual ash.

${ }^{6}$ Calculated according to INRA (2007).

${ }^{7} \mathrm{PDIE}=$ protein digested in the small intestine supplied by rumen undegraded dietary protein and by microbial protein from rumen-fermented OM (INRA, 2007).

${ }^{8} \mathrm{PDIN}=$ protein digested in the small intestine supplied by rumen undegraded dietary protein and by microbial protein from rumen-degraded N (INRA, 2007).

et al., 2014). A $1 \mathrm{~g} / \mathrm{L}$ solution of $\mathrm{Yb}$ was continuously infused into the rumen via the rumen cannula at a rate of $1.2 \mathrm{~L} / \mathrm{d}$ for $10 \mathrm{~d}$ (i.e., $6 \mathrm{~d}$ before the first duodenal sampling) using a peristaltic pump to ensure steady state before duodenal sampling (Owens and Hanson, 1992). Twelve $250-\mathrm{mL}$ duodenal samples were collected over 3 consecutive days of wh 3 (4 samples per day at 3 -h intervals) to obtain representative samples at 1-h intervals between the morning and evening meals. Samples were pooled per animal and per period, and stored at $-20^{\circ} \mathrm{C}$ to determine $\mathrm{Yb}$ and chemical composition.

To calculate bacterial $\mathrm{N}$ flow and microbial protein synthesis, $700 \mathrm{~g}$ of representative rumen content was sampled from several locations of the rumen at each period on the first day of wk 3 , before and $2.5 \mathrm{~h}$ after the morning feed. The solid and liquid phases of the ruminal content were separated by filtration through a polyester monofilament fabric $(250 \mu \mathrm{m}$ pore size). Liquid-associated bacteria were isolated by washing and differential centrifugation as described in Bauchart et al. (1990). Bacteria isolated from pre- and postfeeding samples were pooled, stored at $-20^{\circ} \mathrm{C}$, and then freeze-dried before subsequent analysis of OM, N, and nucleic bases.

Rumen Fermentation Characteristics. Rumen fluid $(100 \mathrm{~mL})$ was sampled by suction through a pipe inserted in the ventral sac just before and at 1, 2.5, 5 , and $8 \mathrm{~h}$ after the morning feed on $2 \mathrm{~d}$ of wk 3 in each period. The $\mathrm{pH}$ was determined using a digital $\mathrm{pH}$ meter (SevenGo SG2 connected to an InLab Expert Pro electrode with a temperature probe; Mettler Toledo SAS, Viroflay, France), and then the samples were immediately strained through a $250-\mu \mathrm{m}$-pore nylon filter. An $0.8-\mathrm{mL}$ aliquot of rumen filtrate was added to 0.5 $\mathrm{mL}$ of a deproteinizing solution (2\% metaphosphoric 
acid and $0.4 \%$ crotonic acid in $0.5 \mathrm{~N} \mathrm{HCl}$ ), cooled at $4^{\circ} \mathrm{C}$ for $4 \mathrm{~h}$, then stored at $-20^{\circ} \mathrm{C}$ until determination of VFA content. Another 1-mL aliquot of rumen filtrate was mixed with $0.1 \mathrm{~mL}$ of $5 \%$ orthophosphoric acid in a microcentrifuge tube, then stored at $-20^{\circ} \mathrm{C}$ for analysis of $\mathrm{NH}_{3}-\mathrm{N}$. The supernatant collected after centrifugation was stored at $-20^{\circ} \mathrm{C}$ until subsequent analysis.

\section{Chemical Analysis}

Alcohol and VFA in corn silage juice samples were assayed by gas chromatography and $\mathrm{NH}_{3}-\mathrm{N}$ was analyzed by the Conway (1957) method. Lactic acid was analyzed by enzymatic method with a Enzyplus D/L-Lactic Acid kit (BioControl Systems Inc., Bellevue, WA), as recommended by Dulphy and Demarquilly (1981). Silage offered, refusals, and duodenal and fecal samples (pooled per animal and period) were dried at $60^{\circ} \mathrm{C}$ for $72 \mathrm{~h}$ before determination of chemical composition. Nitrogen, NDF, ADF, and ADL were analyzed on samples ground through a 1-mm sieve. Starch was analyzed on samples ground through a $0.5-\mathrm{mm}$ sieve. Starch content was determined by the enzymatic method (ISO-15914; ISO, 2004). Content of NDF and ADF were determined according to Van Soest and Wine (1967) on an Ankom system (Ankom Tech, Fairport, NY). The NDF determination used a heat-stable amylase without added sodium sulfite. The ADF residues were obtained after boiling with ADF reagent. The ADL content was determined after cellulose solubilization with sulfuric acid, and expressed minus residual ash (ADLo). The $\mathrm{N}$ content was determined using the Dumas method with an Elementar Rapid N Cube (Elementar France, Lyon, France) based on the ISO-16634-1 (ISO, 2008) method.

The $\mathrm{Yb}$ concentrations in feces and duodenal contents were determined by atomic absorption spectrophotometry (model AA400 spectrophotometer, PerkinElmer, Bois d'Arcy, France) at a 398.8-nm wavelength with an acetylene $/ \mathrm{N}_{2} \mathrm{O}$ flame after extraction of the marker (Ellis et al., 1982). Puric and pyrimidic bases were extracted from liquid-associated bacteria (0.05 g) and duodenal contents $(0.2 \mathrm{~g})$ by hydrolysis with perchloric acid $(70 \%)$ at $100^{\circ} \mathrm{C}$ followed by neutralization with sodium hydroxide $(0.6 \mathrm{~N})$, then quantified by ultra-performance liquid chromatography $(100 \times$ $2.1 \mathrm{~mm}$ Acquity UPLC BEH, $1.7 \mu \mathrm{m}$ column; Waters, Saint-Quentin-en-Yvelines, France) using an isocratic elution method, as described by Fanchone et al. (2013). Nitrogen (Dumas method) and ash $\left(550^{\circ} \mathrm{C}\right.$ for $6 \mathrm{~h}$ ) were measured in freeze-dried liquid-associated bacteria samples using the Elementar Rapid N Cube, as described above.
Rumen samples were pooled per animal and sampling time and per period to analyze VFA and $\mathrm{NH}_{3}-\mathrm{N}$ content. The VFA content in rumen fluid was determined by gas chromatography using crotonic acid as internal standard (Morgavi et al., 2003). The $\mathrm{NH}_{3}-\mathrm{N}$ content in rumen fluid and duodenal samples was determined by colorimetry on an Infinity M200 spectrophotometer (Tecan Austria GmbH, Grödig, Austria) using the phenol-hypochlorite method (Weatherburn, 1967).

Urinary purine derivatives (allantoin and uric acid) were determined by liquid chromatography with diode array detection and a hydrophilic interaction liquid chromatography column, using a ammonium formate:acetonitrile gradient solvent, as described in Cantalapiedra-Hijar et al. (2014).

\section{Calculations}

Duodenal flows were determined as the mean of the duodenal flows calculated using fecal $\mathrm{Yb}$ and fecal ADLo as markers. This allows accounting for variability in fecal recovery [averaging 101\% (SD = 7) of infused $\mathrm{Yb}$ and $129 \%$ (SD = 13) of ADLo intake]. Rumen protein balance was calculated as the difference between $\mathrm{N}$ intake and duodenal nonammonia $\mathrm{N}$ multiplied by 6.25 , and expressed as grams of CP per kilogram of DMI. Apparent ruminal digestion of chemical components was calculated as the difference between their ingested and duodenal flows, and expressed as \% of ingested flow. The OMtDR was calculated as the sum of apparently rumen-digested $\mathrm{OM}$ and duodenal microbial OM flow, and expressed as \% of OM intake. The $\mathrm{N}$ truly digested in the rumen (NtDR) was calculated as the difference between ingested $\mathrm{N}$ from silage (excluding $\mathrm{N}$ from urea) and duodenal nonammonia, nonmicrobial, nonendogenous $\mathrm{N}$ flow (assuming endogenous $\mathrm{N}=2.27$ $\mathrm{g}$ of N/kg of DMI; Sauvant and Nozière, 2016), and expressed as \% of $\mathrm{N}$ intake.

\section{Statistical Analysis}

Data were tested by ANOVA using the MIXED procedure of SAS (9.3 version, 2002; SAS Institute Inc., Cary, NC) with mean per animal and treatment as the experimental unit. The model included animal as random effect, and period, hybrid ( $\mathrm{F}$ vs. FD), maturity (early vs. late), and hybrid $\times$ maturity interaction as fixed effects. For rumen fermentation parameters, the model also included time and hybrid $x$ time, maturity $\times$ time, and hybrid $\times$ maturity $\times$ time interactions as fixed effects, using the REPEATED statement in the MIXED procedure of SAS. Differences between means 
Table 2. Effects of hybrid, maturity stages, and their interaction on BW, and intake of DM and dietary components of corn silage ${ }^{1}$

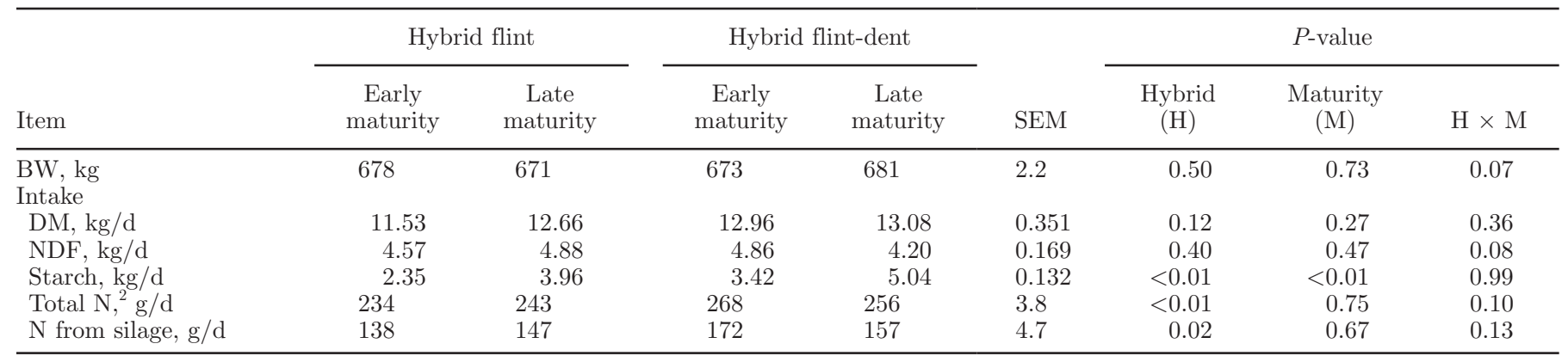

${ }^{1}$ Means of 4 dry cows.

${ }^{2}$ Total $\mathrm{N}=\mathrm{N}$ from silage + urea-N.

were tested using the SLICE statement. Normality of all data distributions was also verified using the UNIVARIATE procedure of SAS.

\section{RESULTS}

\section{Chemical Composition}

Late-maturity corn has a much higher starch content $(+114 \mathrm{~g} / \mathrm{kg}$ of DM on average) but lower NDF, ADF, ADLo, soluble sugars, and digestible protein content than early-maturity corn (Table 1). The late-harvest decrease in NDF and ADF was greater in FD hybrid, whereas the late-harvest decrease in soluble carbohydrates was greater in the $\mathrm{F}$ hybrid. The $\mathrm{N}$ content did not differ among hybrids and maturity stages. Analysis of the fermentation products confirmed that the silages had been adequately conserved.

\section{Body Weight and Feed Intake}

Body weight of the animals was not affected by treatments (Table 2). As expected, DMI did not differ among treatments, averaging $12.6 \mathrm{~kg} / \mathrm{d}$ (i.e., $1.9 \mathrm{~kg}$ per $100 \mathrm{~kg}$ of BW). The NDF decreased with maturity of FD hybrid only $(P=0.08)$. Starch intake was higher $(P<0.01)$ on FD hybrid and increased $(P<0.01)$ with increasing maturity, on average from 2.88 to $4.50 \mathrm{~kg} / \mathrm{d}$. The $\mathrm{N}$ intake was higher on FD hybrid $(P<0.01)$ but did not differ between maturity stages.

\section{Apparent Total-Tract Digestion and Urinary Flows}

Apparent total-tract digestibility of $\mathrm{OM}$ and NDF were not affected by maturity or hybrid (Table 3 ). Apparent digestibility of starch and $\mathrm{N}$ did not differ between hybrids but both were significantly higher at

Table 3. Effects of hybrid, maturity and their interaction on OM, NDF, starch and N apparent total-tract digestion and digestibility, urinary flows of $\mathrm{N}$ and purine derivatives, and $\mathrm{N}$ balance ${ }^{1}$

\begin{tabular}{|c|c|c|c|c|c|c|c|c|}
\hline \multirow[b]{2}{*}{ Item } & \multicolumn{2}{|c|}{ Hybrid flint } & \multicolumn{2}{|c|}{ Hybrid flint-dent } & \multirow[b]{2}{*}{ SEM } & \multicolumn{3}{|c|}{$P$-value } \\
\hline & $\begin{array}{c}\text { Early } \\
\text { maturity }\end{array}$ & $\begin{array}{c}\text { Late } \\
\text { maturity }\end{array}$ & $\begin{array}{c}\text { Early } \\
\text { maturity }\end{array}$ & $\begin{array}{c}\text { Late } \\
\text { maturity }\end{array}$ & & $\begin{array}{c}\text { Hybrid } \\
(\mathrm{H})\end{array}$ & $\begin{array}{l}\text { Maturity } \\
\text { (M) }\end{array}$ & $\mathrm{H} \times \mathrm{M}$ \\
\hline \multicolumn{9}{|c|}{ Apparent total-tract digestion, /d } \\
\hline $\mathrm{OM}, \mathrm{kg}$ & 7.27 & 8.11 & 8.48 & 8.33 & 0.250 & 0.05 & 0.31 & 0.16 \\
\hline $\mathrm{NDF}, \mathrm{kg}$ & 2.03 & 2.42 & 2.42 & 1.67 & 0.155 & 0.43 & 0.44 & 0.02 \\
\hline Starch, kg & 2.33 & 3.76 & 3.42 & 4.75 & 0.121 & $<0.01$ & $<0.01$ & 0.75 \\
\hline $\mathrm{OM}$ & 68.0 & 68.3 & 70.8 & 67.5 & 1.05 & 0.54 & 0.36 & 0.30 \\
\hline NDF & 45.5 & 49.1 & 49.9 & 39.2 & 2.60 & 0.49 & 0.39 & 0.11 \\
\hline Starch & 99.3 & 95.1 & 99.7 & 94.5 & 0.64 & 0.91 & $<0.01$ & 0.62 \\
\hline $\mathrm{N}$ from silage & 44.4 & 39.9 & 51.4 & 37.4 & 2.42 & 0.51 & 0.03 & 0.19 \\
\hline \multicolumn{9}{|l|}{ Urinary flow } \\
\hline $\mathrm{N}, \mathrm{g} / \mathrm{d}$ & 130 & 122 & 117 & 125 & 3.8 & 0.42 & 0.98 & 0.20 \\
\hline Purine derivatives, mmol/d & 169 & 144 & 226 & 180 & 16.5 & 0.08 & 0.17 & 0.65 \\
\hline
\end{tabular}

${ }^{1}$ Means of 4 dry cows.

${ }^{2} \mathrm{~N}$ intake - fecal $\mathrm{N}$ - urinary $\mathrm{N}$. 
Table 4. Effects of hybrid, maturity, and their interaction on $\mathrm{N}$ duodenal flows and rumen protein balance

\begin{tabular}{|c|c|c|c|c|c|c|c|c|}
\hline Item & \multicolumn{2}{|c|}{ Hybrid flint } & \multicolumn{2}{|c|}{ Hybrid flint-dent } & SEM & \multicolumn{3}{|c|}{$P$-value } \\
\hline Total N & 271 & 265 & 320 & 277 & 15.1 & 0.23 & 0.32 & 0.45 \\
\hline $\mathrm{NH}_{3}-\mathrm{N}$ & 9.22 & 8.72 & 9.11 & 9.10 & 0.791 & 0.91 & 0.83 & 0.83 \\
\hline Non- $\mathrm{NH}_{3}-\mathrm{N}$ & 262 & 256 & 311 & 267 & 14.5 & 0.22 & 0.31 & 0.42 \\
\hline 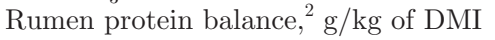 & -10 & -6 & -20 & -5 & 7.2 & 0.68 & 0.39 & 0.63 \\
\hline
\end{tabular}

${ }^{1}$ Means of 4 dry cows.

${ }^{2}$ Rumen protein balance $=6.25$ (total $\mathrm{N}$ intake - non- $\mathrm{NH}_{3}-\mathrm{N}$ duodenal flow $)$.

the early maturity stage than at the late maturity stage $(P<0.01$ and $P=0.03$, respectively $)$.

Urinary flow of $\mathrm{N}$ did not differ with maturity or hybrid. Urinary excretion of purine derivatives tended to be higher with the FD hybrid than $\mathrm{F}$ hybrid $(P=0.08)$ but was not affected by stage of maturity. Maturity $x$ hybrid interaction had a significant effect on $\mathrm{N}$ balance, which declined $(P=0.04)$ with advancing maturity at harvest for the FD hybrid, whereas no effect of maturity was observed for the $\mathrm{F}$ hybrid $(P=0.92$; Table 3$)$.

\section{Duodenal Flows, Ruminal Digestion, Intestinal Digestion, and Microbial Synthesis}

No effects were found of maturity, hybrid, or their interaction on duodenal flows of total $\mathrm{N}, \mathrm{NH}_{3}-\mathrm{N}$, non-
$\mathrm{NH}_{3}-\mathrm{N}$, microbial $\mathrm{N}$, non- $\mathrm{NH}_{3}$ nonmicrobial $\mathrm{N}$, or rumen protein balance (Table 4).

The NDF digested in the rumen, OMtDR, and NtDR were not affected by any of the treatments tested (Table 5). The amount of starch digested in the rumen increased by an average of $1.26 \mathrm{~kg} / \mathrm{d}$ between early and late maturity $(P<0.01)$ for both hybrids, and was higher $(P<0.01)$ with the FD than $\mathrm{F}$ hybrid (3.71 vs. $2.81 \mathrm{~kg} / \mathrm{d}$, respectively, on average for both stages of maturity). Efficiency of microbial synthesis remained unaffected by hybrid or stage of maturity. Ruminal starch digestibility decreased with increasing maturity (from 91.3 to $86.5 \%$ for both $\mathrm{F}$ and FD hybrids; $P<$ $0.01)$ but did not differ between hybrids.

Intestinal starch digestibility decreased with increasing maturity (from 93.9 to $61.6 \%$ on average for both $\mathrm{F}$

Table 5. Effects of hybrid, maturity, and their interaction on NDF, starch and $\mathrm{N}$ ruminal digestion, and ruminal microbial synthesis ${ }^{1}$

\begin{tabular}{|c|c|c|c|c|c|c|c|c|}
\hline Item & \multicolumn{2}{|c|}{ Hybrid flint } & \multicolumn{2}{|c|}{ Hybrid flint-dent } & SEM & \multicolumn{3}{|c|}{$P$-value } \\
\hline NDF & 1.90 & 2.60 & 2.12 & 1.81 & 0.227 & 0.36 & 0.53 & 0.12 \\
\hline Starch & 2.18 & 3.43 & 3.08 & 4.34 & 0.158 & $<0.01$ & $<0.01$ & 0.99 \\
\hline \multicolumn{9}{|l|}{ True ruminal digestion, /d } \\
\hline \multicolumn{9}{|c|}{ Apparent ruminal digestibility, $\%$ intake } \\
\hline NDF & 42.2 & 52.5 & 43.4 & 42.5 & 3.83 & 0.44 & 0.41 & 0.33 \\
\hline Starch & 92.8 & 86.7 & 89.8 & 86.2 & 1.10 & 0.26 & $<0.01$ & 0.41 \\
\hline \multicolumn{9}{|c|}{ True ruminal digestibility, \% intake } \\
\hline $\mathrm{OM}$ & 60.0 & 60.9 & 57.8 & 60.8 & 1.30 & 0.59 & 0.37 & 0.64 \\
\hline $\mathrm{N}$ from silage ${ }^{2}$ & 57.4 & 58.0 & 56.0 & 65.6 & 4.04 & 0.63 & 0.43 & 0.49 \\
\hline \multicolumn{9}{|l|}{ Microbial efficiency parameter } \\
\hline
\end{tabular}

${ }^{1}$ Means of 4 dry cows.

${ }^{2}$ Assuming endogenous duodenal $\mathrm{N}=2.27 \mathrm{~g}$ of N/kg of DMI (Sauvant and Nozière, 2016).

${ }^{3} \mathrm{EMPS}=$ efficiency of microbial protein synthesis, in grams of microbial $\mathrm{N}$ per kilogram of organic matter truly digested in the rumen. OMtDR $=\mathrm{OM}$ truly digested in the rumen.

${ }^{4} \mathrm{ENU}-\mathrm{R}=$ efficiency of $\mathrm{N}$ utilization in the rumen $=$ microbial $\mathrm{N} /$ rumen-available $\mathrm{N}$. 
Table 6. Effects of hybrid, maturity, and their interaction on rumen $\mathrm{pH}, \mathrm{N}-\mathrm{NH}_{3}$ concentration, VFA concentrations, and molar proportions ${ }^{1}$

\begin{tabular}{|c|c|c|c|c|c|c|c|c|}
\hline Item & \multicolumn{2}{|c|}{ Hybrid flint } & \multicolumn{2}{|c|}{ Hybrid flint-dent } & SEM & \multicolumn{3}{|c|}{$P$-value } \\
\hline $\mathrm{N}-\mathrm{NH}_{3}, \mathrm{mg} / \mathrm{L}$ & 83.2 & 88.7 & 74.0 & 113.3 & 8.46 & 0.44 & 0.03 & 0.09 \\
\hline Total VFA, $\mathrm{m} M$ & 89.1 & 95.0 & 92.6 & 98.4 & 2.73 & 0.28 & 0.07 & 0.97 \\
\hline \multicolumn{9}{|l|}{ Individual VFA, mol/100 mol } \\
\hline Iso-butyrate & 0.77 & 1.16 & 0.85 & 1.00 & 0.051 & 0.52 & $<0.01$ & 0.05 \\
\hline Butyrate & 16.4 & 12.2 & 16.1 & 11.8 & 0.803 & 0.71 & $<0.01$ & 0.98 \\
\hline Iso-valerate & 1.02 & 1.99 & 1.15 & 1.66 & 0.082 & 0.29 & $<0.01$ & 0.03 \\
\hline Valerate & 1.64 & 1.39 & 1.66 & 1.43 & 0.103 & 0.79 & 0.06 & 0.94 \\
\hline Caproate & 1.04 & 1.14 & 1.78 & 1.37 & 0.001 & $<0.01$ & 0.21 & 0.05 \\
\hline Acetate/propionate, $\mathrm{mol} / \mathrm{mol}$ & 2.87 & 3.73 & 3.53 & 3.99 & 0.079 & $<0.01$ & $<0.01$ & 0.04 \\
\hline
\end{tabular}

${ }^{1}$ Means of 4 dry cows $\times 5$ sampling times.

${ }^{2}$ Sampling time $=$ before, $1,2.5,5$, and $8 \mathrm{~h}$ after the morning feeding.

and FD hybrids; $P<0.01$ ) but did not differ between hybrids (data not shown).

\section{Ruminal Fermentation}

Mean rumen $\mathrm{pH}$ averaged 6.50 and did not differ among treatments (Table 6). Diurnal pattern of rumen $\mathrm{pH}$ was similar for all corn silages, decreasing significantly from peak $\mathrm{pH}$ (between 6.7 and 6.8) premorning feed to a minimum of 6.25 in FD treatments and 6.40 in $\mathrm{F}$ treatments $5 \mathrm{~h}$ postmorning feed. Mean ruminal $\mathrm{NH}_{3}-\mathrm{N}$ increased from early to late maturity stages. This increase tended to be greater $(P=0.09)$ for the FD hybrid $(+39 \mathrm{mg} / \mathrm{L})$ than F hybrid $(+6 \mathrm{mg} / \mathrm{L}$, Table $6)$. Total mean ruminal VFA concentration did not differ between hybrids but tended to increase $(P=0.07)$ with maturity from 90.8 to $96.7 \mathrm{~m} M$ on average for both hybrids.

Molar proportions of acetate increased with increasing maturity $(P<0.01)$, whereas molar proportions of propionate, butyrate, and valerate decreased $(P=$ $0.03, P<0.01, P=0.06$, respectively) for both hybrids. Maturity $\times$ hybrid interaction had a significant effect on proportions of acetate, iso-butyrate, iso-valerate, and acetate-to-propionate ratio (respectively, $P<$ $0.01, P=0.05, P=0.03, P=0.05$, and $P=0.04$ ), which increased with advancing maturity at harvest for both hybrids. Hybrid FD induced higher proportions of acetate and acetate-to-propionate ratio $(P<0.01$ for all) than hybrid D at all maturity stages, whereas an adverse ranking was observed on average on proportion of propionate $(P=0.02)$. No interaction was found between sampling time and experimental factors (maturity and hybrid) on ruminal $\mathrm{pH}, \mathrm{NH}_{3}-\mathrm{N}$, total VFA, and molar VFA concentrations, except a trend on butyrate $(P=0.08)$.

\section{DISCUSSION}

To our knowledge, no published results are available on digestive flows in cows fed corn silage only. Most in vivo studies published to date have measured digestive flows in lactating cows fed corn silage-plus-concentrate diets, which precludes a specific evaluation of corn silage per se. Here, as expected, DMI was similar among treatments, at close to $2 \mathrm{~kg} / 100 \mathrm{~kg}$ of BW. Given the variations in chemical composition between the 4 studied silages, starch intake highly varied between maturity stages and hybrids. In contrast, only a small variation was observed in $\mathrm{N}$ intake $(+22 \mathrm{~g})$.

\section{Characteristics of Whole-Plant Corn Silage}

The F and FD hybrids studied here differed in starch and NDF contents, mainly due to the between-hybrid difference in earliness. At the same date of harvest, the FD hybrid shows earlier maturity indices (SA) with a higher grain fill than the F hybrid (SB), which explains the higher starch content and lower NDF content in FD than $\mathrm{F}$ hybrid. The atypical climate conditions in year 2012 may have enhanced the earliness-related differences in chemical composition between hybrids. The $\mathrm{N}$ content of the silages ranged from 1.2 to $1.3 \%$ of DM, and was similar among hybrids (as reported by Verbic et al., 2005). In agreement with a review by Khan et al. (2015), and as already integrated in INRA (2007) feed tables, starch content increased and NDF and ADF contents decreased with increasing maturity for hybrid FD. This change in starch and cell wall content was related to the increase in proportion of grain in the corn plants during whole-plant maturation, especially at the grain fill stage, and was accompanied by a slight dip in 
$\mathrm{N}$ content, also as already reported (Sutton et al., 2000; Andrae et al., 2001; Michalet-Doreau et al., 2004).

\section{Digestion of Starch}

In comparison with previous studies where wholeplant corn silage was the main source of starch fed to cows at similar DMI levels (Fernandez et al., 2004), we found a very high total-tract digestibility of starch $(>94 \%)$ in each treatment. Total-tract digestibility of starch decreased by an average 4.7 percentage points between early and late maturity. A similar effect of whole-plant corn silage maturity on starch digestibility is widely reported (Andrae et al., 2001; Fernandez et al., 2004; Jensen et al., 2005) and is more pronounced on lactating cows at higher DMI levels (Harrison et al., 1996; Bal et al., 1997).

Similar to total-tract digestibility, ruminal starch digestibility decreased with increasing maturity by 4.9 percentage points. This figure is consistent with Jochmann et al. (1999), Jensen et al. (2005), and Juniper et al. (2006) but lower than that observed by Fernandez et al. (2004). Peyrat et al. (2014a), studying the same corn hybrids, also reported that harvesting corn silage at later maturity decreased effective ruminal starch degradability measured in situ. These variations could be related to increasing kernel vitreousness with later maturity. Philippeau and Michalet-Doreau (1997) and Correa et al. (2002) have shown in situ that increasing corn vitreousness decreases corn starch degradability in the rumen. This increasing resistance to degradation with increasing kernel vitreousness was related to increasing hardiness (physical barrier) and increasing concentration of insoluble zein protein (chemical barrier) in the protein matrix encapsulating the starch granules in the seed endosperm (Philippeau et al., 2000).

We found no significant effect of hybrid on ruminal starch digestibility. This contrasts with previous studies on corn grain (Philippeau and Michalet-Doreau, 1997; Pereira et al., 2004) showing in situ that vitreous endosperm-rich flint grain has higher ruminal starch degradability than vitreous endosperm-poor dent grain. The lack of significant effect of hybrid on ruminal starch digestibility here is likely partly due to both the degree of precision of duodenal flow measurements and to the type of hybrid used. The hybrids belonged to different types of corn but shared the same group of earliness, which may have limited any between-hybrid differences in ruminal starch digestibility.

The combined effects of hybrid and maturity on both ruminal starch digestibility and starch content induced high variations in rumen-digested starch, ranging from $19 \%$ of DMI on early $\mathrm{F}$ to $33 \%$ of DMI on late FD.
Although starch escaping ruminal digestion did not exceed $6 \%$ of DMI, starch digestion remained incomplete at late maturity stages, averaging just $61.6 \%$ for both hybrids (as also observed by Harrison et al., 1996; Fernandez et al., 2004). The capacity of starch-hydrolyzing enzymes could be a limiting factor for starch digestion in the small intestine that could partly explain incomplete starch digestion (Owens et al., 1986). Here, starch accounted for 4.7 to $6.3 \%$ of fecal DM on late-F and late-FD hybrids, respectively. Fecal starch (\% of fecal $\mathrm{DM})$ was significantly $\left(\mathrm{R}^{2}=0.70\right.$, residual standard deviation $=0.99, \mathrm{n}=16$ ) and positively related to bypass starch (in \% of DMI). These data support the hypothesis that fecal starch content could be a useful indicator of starch digestion partitioning between rumen and intestines.

\section{Digestion of Plant Cell Walls}

Total-tract digestibility of NDF ranged from 39.2 to 49.9\%, consistent with Fernandez et al. (2004). Contrary to many studies (Jochmann et al., 1999; Sutton et al., 2000; Jensen et al., 2005), we did not observe the expected decreases of total-tract NDF digestibility with increasing maturity (except for hybrid FD). Peyrat et al. (2014b) also found that the in vivo total-tract digestibility of NDF in sheep decreased with increasing maturity of the same hybrids harvested as corn silage in other locations. The lack of maturity effect on NDF digestibility came mainly from the $\mathrm{F}$ hybrid $(P$-values for the maturity $\times$ hybrid interaction were 0.11 for NDF), because NDF digestibility decreased by 11 points, respectively, with FD hybrid. This is largely explained by the atypical lack of variation in NDF content between early- and late-F hybrid. Like for totaltract digestibility (except a small variation for hybrid FD), maturity stage had no significant effect on the rumen digestibility of NDF. Peyrat et al. (2014a) also found no effect of maturity on the in situ degradability of NDF. However, Fernandez et al. (2004) showed in vivo that maturity had a depressive effect on ruminal NDF digestibility, but only with long-chopped corn. In line with Taylor and Allen (2005) and Verbic et al. (2005), we found no effect of hybrid on whole-tract and rumen NDF digestibility.

\section{Ruminal Nitrogen Digestion}

No maturity stage or hybrid-related effects were found on duodenal flows of ammonia N, microbial N, and nonammonia, nonmicrobial $\mathrm{N}$, which accounted for $3.2,64.4$, and $32.4 \%$ of total N, respectively. Assuming that endogenous duodenal $\mathrm{N}$ flow accounted for $2.27 \mathrm{~g}$ of N/kg of DMI (Sauvant and Nozière, 2016), NtDR 
averaged $59 \%$, which is in the range of values (54-80\%) in a recent review (Ali et al., 2014) based on in situ degradability measurements. Rumen protein balance (RPB) is the difference between $\mathrm{N}$ intake and duodenal non- $\mathrm{NH}_{3}-\mathrm{N}$. Assuming an endogenous duodenal $\mathrm{N}$ of $14.2 \mathrm{~g}$ of $\mathrm{CP} / \mathrm{kg}$ of DMI (Sauvant and Nozière, 2016), a RPB close to $-14 \mathrm{~g} / \mathrm{kg}$ of DMI is expected when the rumen reaches an adequate net balance between energy and nitrogen. This was the case here, as $\mathrm{RPB}$ ranged from -20 to -5 , averaging $-10 \mathrm{~g} / \mathrm{kg}$ of DMI. This adequate balance between energy and available nitrogen in the rumen is also reflected by rumen $\mathrm{NH}_{3}-\mathrm{N}$ concentrations, which ranged from 74 to 113 $\mathrm{mg} / \mathrm{L}$ (average $90 \mathrm{mg} / \mathrm{L}$ ), thus confirming the adequate urea supplementation of $15 \mathrm{~g}$ of urea per $\mathrm{kg}$ of DMI (INRA, 2007).

\section{OM Fermentation and Microbial Growth}

The OMtDR and microbial synthesis did not vary significantly among treatments. This is in line with the fact that rumen microbial growth is the main driver of OMtDR and type of rumen-fermented energy has little or unmeasurably low quantitative effect, as discussed by Sauvant and Nozière (2016). Here, efficiency of microbial synthesis averaged $26.3 \mathrm{~g}$ of microbial $\mathrm{N} / \mathrm{kg}$ of OMtDR, which is close to values set under the current French PDI protein evaluation system (23.2 g of microbial N/kg of OMtDR; INRA 2007) or recalculated with the revised version $(24.7 \mathrm{~g}$ of microbial $\mathrm{N} / \mathrm{kg}$ of OMtDR) according to Sauvant and Nozière (2016).

Note too that OMtDR, calculated as measured OM apparently digested in the rumen plus microbial OM, is similar to the sum of its dietary fermented fractions $(6.25 \times \mathrm{N}$, starch, NDF, soluble carbohydrates $)$ plus silage fermentation products. Across 16 individual animal measures, OMtDR ranged from 447 to $668 \mathrm{~g} / \mathrm{kg}$ of DMI (mean $=560, \mathrm{SD}=66$ ) and the relationship between the 2 approaches did not significantly differ from the first bisector, which confirms that the duodenal flow measurements remained consistent.

Ruminal ammonia concentrations increased with increasing maturity, as also reported by Fernandez et al. (2004), Jensen et al. (2005), and Juniper et al. (2006). This increase may be related to both efficiency of microbial protein synthesis ( $\mathrm{g}$ of microbial $\mathrm{N} / \mathrm{kg}$ of OMtDR) and efficiency of $\mathrm{N}$ utilization in the rumen [ENU-R; i.e., the ratio between microbial $\mathrm{N}$ and rumen-available $\mathrm{N}$ (urea $\mathrm{N}$ plus $\mathrm{N}$ truly fermented from silage) as defined by Bach et al. (2005) and Calsamiglia et al. (2010)]. Nevertheless, both indexes did not differ between early and late maturity stages. The quantitative effect of energy source (NDF vs. starch or sugars) in OMtDR on ENU-R and efficiency of microbial pro- tein synthesis remains controversial (Calsamiglia et al., 2010; Fanchone et al., 2013) and uneven across most recent feed system updates (Volden, 2011; Van Duinkerken et al., 2011; Sauvant and Nozière, 2016). Here, ENU-R values were close to 1 , reflecting an adequate ratio between available $\mathrm{N}$ and energy in the rumen.

\section{Ruminal Fermentations}

Rumen $\mathrm{pH}$ did not vary significantly between treatments. Total VFA concentrations were unaffected by hybrid and tended to increase slightly with maturity, consistent with the lack of variation in OMtDR and microbial flow among treatments. In contrast, VFA profiles varied widely among treatments. Molar proportion of acetate increased significantly, whereas molar proportions of propionate and butyrate decreased with increasing maturity. Although already observed by other teams (Jensen et al., 2005; Juniper et al., 2006), such variations differ from the apparent consensus of a lower proportion of acetate to total VFA associated with a higher contribution of starch to rumen-digested total carbohydrate (Sutton et al., 2000). The main digestive factors affecting molar proportions of VFA in the rumen (i.e., digested NDF-to-digested OM ratio, DMI level, and rumen starch digestibility; Nozière et al., 2011) changed little among treatments $(0.20$ to $0.30,17$ to $19 \mathrm{~g}$ of $\mathrm{DM} / \mathrm{kg}$ of $\mathrm{BW}$, and 86 to $93 \%$, respectively). This suggests that changes in molar VFA proportions observed in the present study are attributable to other factors. For the F hybrid, the increase in molar proportion of acetate between early and late maturity stages may be related to the increase in contribution of NDF to OMtDR (from 30 to 35\%). Contributions of other carbohydrates (starch + sugars) remained constant (from 50 to $49 \%$ ). For the FD hybrid, the contribution of NDF to OMtDR was low $(<30 \%)$, which underlines the difficulty of accurately predicting molar VFA proportions in low-fiber-content diet conditions. The elevated rumen $\mathrm{pH}$ and the restricted feeding may have enhanced fermentation of starch toward more acetate (Van Soest, 1994; Lana et al., 1998; Freetly et al., 2008).

\section{Nitrogen Balance}

Apparent total-tract digestibility of $\mathrm{N}$ from silage decreased from early to late maturity stages from 47.9 to $38.6 \%$ on average, in line with Bal et al. (1997), INRA (2007), and Khan et al. (2015). This decrease could be related to the increase in insoluble protein (zein and glutelin) in the grain fraction of corn as it gains in maturity (Michalet-Doreau et al., 2004). This decrease also led to increased fecal $\mathrm{N}$ flow, whereas urinary $\mathrm{N}$ flow did not vary among treatments, consistent 
with RPB, which also did not differ among treatments. Whole-animal $\mathrm{N}$ balance (i.e., the difference between $\mathrm{N}$ intake and $\mathrm{N}$ excretion in feces and urines) remained positive whatever the dietary treatment and was highest on early-stage FD. As the cows were nonpregnant adults that did not change $\mathrm{BW}$, the positive $\mathrm{N}$ balance may reflect a $\mathrm{N}$ balance default rather than $\mathrm{N}$ retention by cows. Spanghero and Kowalski (1997) reported that most classical $\mathrm{N}$ balance studies in cows overestimate $\mathrm{N}$ balance.

\section{CONCLUSIONS}

This study investigated 2 hybrids with contrasting endosperm type harvested at different maturity stages. Later harvesting had no significant effect on truly rumen-digested OM, microbial $\mathrm{N}$ supply, or apparent total-tract $\mathrm{OM}$ digestibility. In contrast, later harvesting led to a large shift in proportion of starch in truly rumen-digested OM that in turn affected nutrient profile on rumen fermentation. Later harvesting also decreased ruminal starch digestibility and increased the amount of starch escaping ruminal digestion, and these changes were only partly compensated by intestinal digestion. The net result was a higher amount of starch in feces. Adjusting date of corn harvest to modulate amount of rumen-digested starch could be used as a strategy to control nutrient delivery to livestock.

\section{ACKNOWLEDGMENTS}

This study was financed by the French Seed Companies Union and the French National Federation of Sorghum and Maize Seed Producers. Julie Peyrat had a $\mathrm{PhD}$ grant funded by the French national tech research agency (ANRT) and Arvalis-Institut du Végétal (La Chapelle St-Sauveur, France). The authors thank their colleagues at the Unité Mixte de Recherches sur les Herbivores and the Unité Expérimentale sur les Ruminants de Theix, INRA, St-Genès-Champanelle, France: H. Albarello and S. Rudel for help with managing the experiment; D. Durand and P. Gaydier for animal surgery; B. Robert and the staff of Les Cèdres for help with animal care; F. Anglard for help with sampling; and P. Amblard, L. Genestoux, S. Laverroux, and A. Quereuil for their valuable technical support.

\section{REFERENCES}

Ali, M., G. van Duinkerken, J. W. Cone, A. Klop, M. C. Blok, J. W. Spek, M. H. Bruinenberg, and W. H. Hendriks. 2014. Relationship between chemical composition and in situ rumen degradation characteristics of maize silages in dairy cows. Animal 8:1832-1838.

Andrae, J. G., C. W. Hunt, G. T. Pritchard, L. R. Kennington, J. H. Harrison, W. Kezar, and W. C. Mahanna. 2001. Effect of hybrid, maturity, and mechanical processing of corn silage on intake and digestibility by beef cattle. J. Anim. Sci. 79:2268-2275.

Bach, A., S. Calsamiglia, and M. D. Stern. 2005. Nitrogen metabolism in the rumen. J. Dairy Sci. 88(E. Suppl.):E9-E21.

Bal, M. A., J. G. Coors, and R. D. Shaver. 1997. Impact of the maturity of corn for use as silage in the diets of dairy cows on intake, digestion, and milk production. J. Dairy Sci. 80:2497-2503.

Barrière, Y., O. Argillier, M. Michalet-Doreau, Y. Hébert, E. Guingo, C. Giauffret, and J. C. Emile. 1997. Relevant traits, genetic variation and breeding strategies in early silage maize. Agronomie. (Paris) 17:395-411.

Bauchart, D., F. Legay-Carmier, M. Doreau, and B. Gaillard. 1990. Lipid metabolism of liquid-associated and solid-adherent bacteria in rumen contents of dairy cows offered lipid-supplemented diets. Br. J. Nutr. 63:563-578.

Beauchemin, K. A., and W. Z. Yang. 2005. Effects of physically effective fiber on intake, chewing activity, and ruminal acidosis for dairy cows fed diets based on corn silage. J. Dairy Sci. 88:2117-2129.

Calsamiglia, S., A. Ferret, C. K. Reynolds, N. B. Kristensen, and A. M. van Vuuren. 2010. Strategies for optimizing nitrogen use by ruminants. Animal 4:1184-1196.

Cantalapiedra-Hijar, G., J. L. Peyraud, S. Lemosquet, E. Molina-Alcaide, H. Boudra, P. Nozière, and I. Ortigues-Marty. 2014. Dietary carbohydrate composition modifies the milk $\mathrm{N}$ efficiency in late lactation cows fed low crude protein diets. Animal 8:275-285.

Cochran, R. C., D. C. Adams, J. D. Wallace, and M. L. Galyean. 1986. Predicting digestibility of different diets with internal markers: Evaluation of four potential markers. J. Anim. Sci. 63:1476-1483.

Conway, E. J. 1957. Microdiffusion Analysis and Volumetric Error. Crosby Lockwood, London, UK.

Correa, C. E. S., R. D. Shaver, M. N. Pereira, J. G. Lauer, and K. Kohn. 2002. Relationship between corn vitreousness and ruminal in situ starch degradability. J. Dairy Sci. 85:3008-3012.

Dulphy, J. P., and C. Demarquilly. 1981. Problèmes particuliers aux ensilages. Pages 81-104 in Prévision de la Valeur Nutritive des Aliments. INRA, Paris, France.

Dulphy, J.-P., C. Demarquilly, M. Henry, M. Jailler, J. Jamot, and L. L'hotelier. 1975. Perte de composés volatils lors de la détermination à l'étuve de la teneur en matière sèche des ensilages. Ann. Zootech. (Paris) 24:743-756.

Ellis, W. C., C. Lascano, R. Teeter, and F. N. Owens. 1982. Solute and particulate flow markers. Pages $37-56$ in Protein Requirements for Cattle. F. N. Owens, ed. Oklahoma State University, Stillwater.

Fanchone, A., P. Nozière, J. Portelli, B. Duriot, V. Largeau, and M. Doreau. 2013. Effects of nitrogen underfeeding and energy source on nitrogen ruminal metabolism, digestion, and nitrogen partitioning in dairy cows. J. Anim. Sci. 91:895-906.

Fernandez, I., P. Nozière, and B. Michalet-Doreau. 2004. Site and extent of starch digestion of whole-plant maize silages differing in maturity stage and chop length in dairy cows. Livest. Prod. Sci. 89:147-157.

Freetly, H. C., J. A. Nienaber, and T. Brown-Brandl. 2008. Partitioning of energy in pregnant beef cows during nutritionally induced body weight fluctuation. J. Anim. Sci. 86:370-377.

Harrison, J. H., L. Johnson, R. Riley, S. Xu, and K. Loney. 1996. Effect of harvest maturity of whole plant corn silage on milk production and component yield, and passage of corn grain and starch into feces. J. Dairy Sci. 79(Suppl. 1):149.

Huntington, G. B. 1997. Starch utilization by ruminants: From basics to the bunk. J. Anim. Sci. 75:852-867.

INRA. 2007. Alimentation des bovins, ovins et caprins-Besoins des animaux-Valeurs des aliments-Tables INRA 2007. Editions Quae, Versailles, France.

ISO. 2004. ISO-15914: Animal feeding stuffs-Enzymatic determination of total starch content. International Organization for Standardization, Geneva, Switzerland.

ISO. 2008. ISO-16634-1: Food products-Determination of the total nitrogen content by combustion according to the Dumas principle and calculation of the crude protein content-Part 1: Oilseeds and animal feeding stuffs. International Organization for Standardization, Geneva, Switzerland. 
Jensen, C., M. R. Weisbjerg, P. Norgaard, and T. Hvelplund. 2005. Effect of maize silage maturity on site of starch and NDF digestion in lactating dairy cows. Anim. Feed Sci. Technol. 118:279-294.

Jochmann, K., P. Lebzien, R. Daenicke, and G. Flachowsky. 1999. Influence of corn maturity and lactic acid bacteria during ensilage on nutrient conversion in the dairy cow digestive tract. J. Anim. Physiol. Anim. Nutr. (Berl.) 82:178-192.

Johnson, L. M., J. H. Harrison, D. Davidson, M. Swift, W. C. Mahanna, and K. Shinners. 2002. Corn silage management II: Effects of hybrid, maturity, and mechanical processing on digestion and energy content. J. Dairy Sci. 85:2913-2927.

Juniper, D. T., E. M. Browne, M. J. Bryant, and D. E. Beever. 2006. Digestion, rumen fermentation and circulating concentrations of insulin, growth hormone and IGF-1 in steers given maize silages harvested at three stages of maturity. Anim. Sci. 82:41-48.

Khan, N. A., P. Yu, M. Ali, J. W. Cone, and W. H. Hendriks. 2015. Nutritive value of maize silage in relation to dairy cow performance and milk quality. J. Sci. Food Agric. 95:238-252.

Kozloski, G. V., C. M. Stefanello, F. R. Mesquita, T. P. Alves, H. M. N. Ribeiro Fiho, J. G. R. Almeida, and T. C. Moraes Genro. 2014 Technical note: Evaluation of markers for estimating duodenal digesta flow and ruminal digestibility: Acid detergent fiber, sulfuric acid detergent lignin, and n-alkanes. J. Dairy Sci. 97:1730-1735.

Lana, R. P., J. B. Russell, and M. E. Van Amburgh. 1998. The role of $\mathrm{pH}$ in regulating ruminal methane and ammonia production. $\mathrm{J}$. Anim. Sci. 76:2190-2196.

Lopes, J. C., R. D. Shaver, P. C. Hoffman, M. S. Akins, S. J. Bertics, H. Gencoglu, and J. G. Coors. 2009. Type of corn endosperm influences nutrient digestibility in lactating dairy cows. J. Dairy Sci. 92:4541-4548.

Michalet-Doreau, B., F. Corneloup, B. Aizac, J. Andrieu, and R. Baumont. 2004. Variabilité et facteurs de variation de la teneur en matières azotées des maïs récoltés en plantes entières. INRA Prod. Anim. 17:3-10.

Morgavi, D. P., H. Boudra, J. P. Jouany, and D. Graviou. 2003. Prevention of patulin toxicity on rumen microbial fermentation by $\mathrm{SH}-$ containing reducing agents. J. Agric. Food Chem. 51:6906-6910.

Nozière, P. F. G., and D. Sauvant. 2010. In vivo production and molar percentages of volatile fatty acids in the rumen: A quantitative review by an empirical approach. Animal 5:403-414.

Opsi, F., G. Borreani, E. Tabacco, and S. Lopez. 2013. Influence of cultivar, sowing date and maturity at harvest on yield, digestibility, rumen fermentation kinetics and estimated feeding value of maize silage. J. Agric. Sci. 151:740-753.

Owens, F. N., and C. F. Hanson. 1992. External and internal markers for appraising site and extent of digestion in ruminants. J. Dairy Sci. 75:2605-2617.

Owens, F. N., R. A. Zinn, and Y. K. Kim. 1986. Limits to starch digestion in the ruminant small intestine. J. Anim. Sci. 63:1634-1648.

Pereira, M. N., R. G. V. Pinho, R. G. S. Bruno, and G. A. Calestine. 2004. Ruminal degradability of hard or soft texture corn grain at three maturity stages. Sci. Agric. (Piracicaba, Brazil) 61:358-363.

Peyrat, J., P. Nozière, A. Le Morvan, A. Férard, P. V. Protin, and R. Baumont. 2014a. Effects of ensiling maize and sample condition- ing on in situ rumen degradation of dry matter, starch and fibre. Anim. Feed Sci. Technol. 196:12-21.

Peyrat, J., P. Nozière, A. Le Morvan, A. Férard, P. V. Protin, and R. Baumont. 2014b. Digestibility of starch and cell wall of maize silage: Consequences on the prediction of organic matter digestibility. Anim. Prod. Aust. 30, 30th Biennial Conference Proc., Canberra, Australia.

Philippeau, C., J. Landry, and B. Michalet-Doreau. 2000. Influence of the protein distribution of maize endosperm on ruminal starch degradability. J. Sci. Food Agric. 80:404-408.

Philippeau, C., and B. Michalet-Doreau. 1997. Influence of genotype and stage of maturity of maize on rate of ruminal starch degradation. Anim. Feed Sci. Technol. 68:25-35.

Sauvant, D., and P. Nozière. 2016. Quantification of the main digestive processes in ruminants: The equations involved in the renewed energy and protein feed evaluation systems. Animal http://dx.doi. org/10.1017/S1751731115002670.

Siddons, R. C., J. Paradine, D. E. Beever, and P. R. Cornell. 1985. Ytterbium acetate as a particulate-phase digesta-flow marker. Br. J. Nutr. 54:509-519.

Spanghero, M., and Z. M. Kowalski. 1997. Critical analysis of N balance experiments with lactating cows. Livest. Prod. Sci. 52:113122.

Sutton, J. D., S. B. Cammell, R. H. Phipps, D. E. Beever, and D. J. Humphries. 2000. The effect of crop maturity on the nutritional value of maize silage for lactating dairy cows 2 . Ruminal and postruminal digestion. Anim. Sci. 71:391-400.

Tang, S. X., F. W. Li, J. Gan, M. Wang, C. S. Zhou, Z. H. Sun, X. F. Han, and Z. L. Tan. 2011. Effects of sown season and maturity stage on in vitro fermentation and in sacco degradation characteristics of new variety maize stover. Asian-australas. J. Anim. Sci. 24:781-790.

Taylor, C. C., and M. S. Allen. 2005. Corn grain endosperm type and brown midrib 3 corn silage: Ruminal fermentation and $\mathrm{n}$ partitioning in lactating cows. J. Dairy Sci. 88:1434-1442.

Van Duinkerken, G., M. C. Blok, A. Bannink, J. W. Cone, J. Dijkstra, A. M. van Buren, and S. Tamminga. 2011. Update of the Dutch Protein Evaluation System for Ruminants: The DVE/OEB2010 system. J. Agric. Sci. 149:351-367.

Van Soest, P. J. 1994. Nutritional Ecology of the Ruminant. Cornell University Press, Ithaca, NY.

Van Soest, P. J., and R. H. Wine. 1967. Use of detergents in the analysis of fibrous feeds. IV. Determination of plant cell-wall constituents. J. Assoc. Off. Anal. Chem. 50:50-55.

Verbic, J., D. Babnik, V. Znidarsic-Pongrac, M. Resnik, A. Gregorcic, and V. Kmecl. 2005. The effect of dent versus flint maize genotype on site and the extent of starch and protein digestion, ruminal fermentation and microbial protein synthesis in the rumen of sheep. Anim. Res. 54:443-458.

Volden, H. 2011. NorFor-The Nordic feed evaluation system. EEAP Publications No. 130, Wageningen Academic Publishers, Wageningen, the Netherlands.

Weatherburn, M. W. 1967. Phenol-hypochlorite reaction for determination of ammonia. Anal. Chem. 39:971-974. 